\title{
From propolis to designer biomaterials for the applications in the veterinary medicine: copazan herbal gel with beepolis and wound healing in vitro
}

\begin{abstract}
In light of the scarcity of novel therapeutic agents that are effective, the pharmaceutical industry has found a newer source of therapeutic compounds in natural products and herbal medicine to address the current health problems in humans and animals. What is particularly promising about these agents is that they produce fewer side effects and are more cost effective than synthetic compounds. This means greater availability of these treatments particularly for less developed countries who can't afford expensive treatments. The reduced side effects also mean greater patient tolerance and increased compliance thereby yielding maximal therapeutic effect without negatively impacting on quality of life.

Among the natural products more frequently employed nowadays is propolis, a resin that is routinely collected by bees (Apis mellifera). Propolis contains flavonoids, caffeic acid esters and diterpenic acids, which provide the bactericidal, antiviral and antifungal properties to this product. The use of propolis to address a variety of conditions in small animal species is beginning to play an important role in the currently available treatments. Its use appears to be an effective treatment with no side effects at low cost. This paper reviews the different applications of this compound to treat diseases in dogs. The novel biomaterials Copazan Herbal Gel with Beepolis have been designed to be used in veterinary medicine for the wound healing application. In vitro investigations highlight the suitability of this material for a variety of applications in the veterinary medicine in the future.
\end{abstract}

Volume 4 Issue I - 2018

Tamara PerchyonokV

Research and development, Australia

Correspondence: Tamara PerchyonokV, Research and development,VTPCHEM PTY LTD, Glenhuntly, Melbourne, 3163, Australia, Email tamaraperchyonok@gmail.com

Received: December 23, 2017 | Published: January 12, 2018

\section{Introduction}

Since early ages, all living vertebrate species have interacted with pathogenic microorganisms that caused several disease states; at that time nature provided its own solutions to maintain balance in the environment. With time and observation, human beings were able to identify the therapeutic effects of available plants and natural resources and developed a form of medicine known as "natural medicine." Natural medicine uses natural remedies for the treatment and prevention of disease states. Among the natural agents, propolis has been used in the treatment of disease. At the initial stages, the use of propolis in veterinary medicine was limited to antibacterial applications, but as time went by, newer applications were discovered for this product used by bees.

Propolis is a resin collected by bees from plants and trees in their surrounding environment. This product is used by the bees in order to close the combs inside of the hive, buttress the walls, and provide greater support to the hive's panels. It is also used to embalm their natural enemies and dead bee bodies that are too large for the bees to remove from the hive. A major function of propolis is to protect the hive of infectious disease that threatens the colony. ${ }^{1}$ In the process of collecting, transporting, and storing the propolis, the bees add enzymes that confer invaluable therapeutic properties in veterinarian medicine, but also in human medicine. The presence of flavonoid compounds, caffeic acid esters and diterpenic confers its bacteriostatic, bactericidal, anti- viral and fungicidal properties to this product. This has been exhaustively documented in vitro and in vivo studies. ${ }^{2}$
In veterinary medicine, propolis is used in a variety of circumstances as described below. For example, propolis used as ointment to control mastitis in milking cows. In pig herds, it is used as a prophylactic agent for respiratory and gastrointestinal diseases by adding $5 \%$ propolis to milk. It is also used as a stimulant for the growth of under developing rams, pigs, and calves. Other uses can be as a prophylaxis to counteract typhoid fever in ducks, wounds healing, and as a local anesthetic for surgery. Notably, in the canine species, the use of propolis has had a number of effective applications that are reviewed below. ${ }^{2}$

\section{Uses and perspectives of propolis in dogs}

\section{Neoplasia}

Transmissible venereal tumor: Propolis has been used in oncology for the treatment of transmissible venereal tumors (TVTs). TVT is a contagious neoplasia that is transmitted sexually and it only affects canines. The origin of TVT is unclear, spread throughout the world, but is most frequently seen in tropical and subtropical regions. There is no existing genetic or racial predisposition for TVT but the greatest prevalence of this disease is observed in animals during their reproductive age. It is diagnosed primarily through cytology or by histological exam. A cytological evaluation of a hypodermic needle used to sample TVT reveals the presence of abundant oval and round cells. TVT can metastasize and be found outside of the genital region. TVT has been treated with chemotherapy with the disadvantage of the unwanted side effects and in many cases the tumor grows back at the same place or is resistant to this treatment. ${ }^{3}$ 
Studies performed in Brazil by Bassani-Silva et al. ${ }^{3}$ evaluated the use of propolis to treat TVT by applying different concentrations of propolis to TVT cells obtained through a biopsy of infected dogs and observing its effects after 6, 24, and 48 hours post-exposure. After six hours, researchers observed significant antiretroviral activity and a significant reduction in viral load, but the effect was transient. ${ }^{3}$ In addition to the compounds mentioned previously, the Brazilian propolis is reported to have Artepilin C, which appears to have a significant cytotoxic activity against tumor cells in vitro. This cytotoxicity was related with the fragmentation of DNA and the induction of apoptosis. ${ }^{3}$

\section{Canine osteosarcoma}

Another form of propolis that has been investigated is geopropolis that is employed in the elimination of Canine Osteosarcoma (OSA) cells. Geopropolis is produced by bees without stingers (Melipona fasciculate Smith), which collect the resin of plants and add soil or clay to it. The actual biological properties of geopropolis or the additives have not been specifically identified as is the case of the propolis produced by Apis mellifera. However, it has been suggested to have antimicrobial, anti-inflammatory, and anti-tumoral activity. Even though a number of studies had aimed to study its antitumor activity, little is known about the cytoxic activity of geopropolis with OSA, a malignant tumor common among dogs. Canine OSA has many similarities with osteosarcoma found in human pediatric patients. Thus, OSA studies in dogs may be useful to evaluate its use in the treatment of this disease in humans. Costa Cinegaglia et al. ${ }^{4}$ studied the effect of incubating geopropolis with osteosarcoma cells at different concentrations and exposure times $(50 \mu \mathrm{g}$ for 6 and $24 \mathrm{~h}$; and $10 \mu \mathrm{g}$ for 48 and $72 \mathrm{~h}$ ). They concluded that osteosarcoma cells were susceptible to the effects of geopropolis at all concentrations and all times.

\section{Cushing's syndrome}

Cushing's syndrome in dogs is usually caused by a neoplasm in the adrenal glands or pituitary gland. It is re- ported that the use of propolis in water (WPP) may be an alternative treatment. In four dogs with different stages of this syndrome, without pretreatment, WPP were administered orally $(0.4-0.5 \mathrm{~g}$ crude propolis per $\mathrm{kg}$ body weight) every 12 hours for three months. Of these, upon completion of treatment, three had a full recovery. This demonstrates the utility that WPP may have. ${ }^{5}$

\section{Bacterial infections}

Among the bacteria that cause disease in dogs, Staphylococcus aureus is of great importance. Bacteria in this genus are considered saprophyte bacteria on the skin and in mucosal surfaces in animal and in men. Infections with Staphylococcus species are classified by their pathogenicity as coagulase negative (e.g., S. epidermidis, $S$. saprophyticus) and coagulase positive (e.g., S. aureus, S. intermedius and $S$. hycus). More than $60 \%$ of the pyogenic infections on the skin, known as pyoderma of the skin in dogs, are caused by coagulase positive species, particularly $S$. aureus and $S$. intermedius. These are considered the causative pathogens of the disease and could possibly lead to development of chronic or recurrent pyoderma, which in turn can result in a secondary infection caused by Pseudomonas species, Proteus species and Escherichia coli. ${ }^{6}$ Dogs are considered reservoirs of drug-susceptible bacteria and drug-resistant bacteria such as $S$. aureus. This has led to research new alternative treatments, one of them being ethanolic extracts of propolis for topical appli-cations, an alternative that has proven to be effective and inexpensive. ${ }^{7}$ Exposure of $S$. aureus to ethanolic extracts of propolis $(20 \%-40 \%)$ was effective in these concentrations. ${ }^{8}$ However, this effect was modest when compared to the inhibition of bacterial growth by penicillin. ${ }^{6}$

\section{Canine otitis}

Otitis External (OE), commonly known as an "ear infection", is a condition characterized by the inflammation of the external auditory canal. Infections of the ear are one of the main reasons that a dog is taken to the veterinarian for treatment. Dogs diagnosed with $\mathrm{OE}$ often exhibit inflammation and erythema in the epithelial tissue of the external auditory canal. There is also an increase in wax secretion by the ear glands, itching, and changes in behavior. Environmental factors such as hot weather and humidity can influence the incidence of $\mathrm{OE}$ in dogs. ${ }^{9-11}$

Malassezia pachydermatisis the yeast most commonly isolated from cultures of patients affected by OE, whereas Candida spp. is observed infrequently in the exudate of dogs with OE. In the majority of the samples, Malassezia pachydermatisis associated with $S$. aureus, which confirms the symbiosis between these two microorganisms. It has been demonstrated that the application of topical extracts of propolis is a new therapy for the treatment of $\mathrm{OE}$ in dogs. This is no surprise given the wide antimicrobial spectrum, an anti-inflammatory effect of this compound, with the added bonus of being inexpensive and free of side effects. Thus, a formulation for ear drops that has sufficient viscosity to remain in the ear would be desirable for the treatment of Otitis External. ${ }^{10}$

\section{Dermatophytosis}

This is a superficial infection of the skin caused by pathogenic dermatophytes of the genus Epidermophyton, Trichophyton, and Microsporum. Dermatophytes live in keratinized tissue such as nails, hair follicles, hair and the stratum corneum of the skin. These pathogens are very important clinically because of its high zoonotic potential. Several treatments have been proposed to treat these diseases, but most of them are inefficient or cause collateral effects. New antimycotic treatments have incorporated natural compounds such as propolis. These treatments have reported to effective in three dogs with dermatophytosis. After diagnosis, the treatment for the dogs consisted of weekly baths with a commercial soap made with propolis for 3 to 8 weeks plus application of a topical ointment all days for three weeks. After two weeks of treatment, all bacterial cultures were negative and by the end of the treatment the three dogs recovered from their lesions. This demonstrated that the use of alternative antimycotic compounds such as propolis would limit the development of infections by Microsporum. ${ }^{12}$

\section{Parasitosis}

Giardiasis and Trypanosomiasis are parasitic infections experienced by dogs and cats. The use of propolis and metronidazol was evaluated in mice infected with Giardia lamblia. The combined therapy showed a stronger efficacy in reducing the parasitic count than that gained by each drug alone. The use of propolis alone significantly reduced the intensity of infection and elicited a significant increase in the serum levels of cytokines and interferon gamma. However, the synergistic effect of both compounds resulted in an immunological balance that was more balanced in terms of the T-lymphocyte profile that protected the intestinal homeostasis and histological architecture. ${ }^{13}$ 
Gressler et al. ${ }^{14}$ studied the susceptibility of T. Evansito propolis in infected rats. Propolis was administered orally to these rats at doses of $100-400 \mathrm{mg} / \mathrm{kg}$ daily for ten days. Even though all rats eventually of the disease, those treated with the highest dose lived twice as long as those treated with the smallest dose indicating that the propolis extract can prolong life in rats infected with the protozoan. These studies suggest that propolis may be of use in treating small species infected with T. Evansi.

\section{Enhancement of the immune response}

Immunization or vaccination aims to prevent or decrease the signs and symptoms of a determined disease in animals or humans. However, often vaccines by themselves are not capable of elicit a robust or protective immune response and requires the use of adjuvants. These compounds increase or enhance the immunogenicity of the antigen in the vaccine and increase the protective period of the vaccine. It is also possible that the addition of adjuvants to vaccine formulations may allow decreasing the amount of the antigen required to elicit a protective immune response or increase the duration of the protective effect.

The ideal adjuvant should enhance the cellular and humoral immune responses and have little to non-biological activity by itself and if possibly, be biodegradable and inexpensive. Most of the adjuvants currently in use do not fulfill all these requirements and research efforts are being directed to find other sources of adjuvants, such as natural products. One of the many properties of propolis is to be able to enhance the immune response..$^{15}$

Recent studies have demonstrated that the addition of the ethanolic extract of propolis to the canine parvovirus vaccine (CPV) and canine corona virus $(\mathrm{CCoV})$ enhanced the production of antibodies against these pathogens in rats. IgG was measured in the serum of immunized animals 21 days after the third dose. Titers indicated that the addition of propolis improved the serum specificity of $\operatorname{IgG}$ toward CPV in animals immunized with the highest antigen dose without influencing the antibodies against $\mathrm{CCoV}$. These results indicate that propolis has an immunomodulatory activity that is dependent of the type and concentration of the used antigen, as demonstrated by increasing antibody titers against CPV. Other studies show a similar enhanced immunity in the case of canine distemper. ${ }^{15,16}$

\section{Periodontal disease}

The potential effect of propolis in the treatment of periodontal disease among dogs should not be overlooked. Having a prevalence of $80 \%$, it is the most common oral disease in dogs. This disease is progressive and has two stages: gingivitis (reversible) and periodontitis (irreversible). It is caused by the accumulation of plaque on the teeth. The plaque is a smooth layer formed by bacteria, non-living particulate organic material, cell debris and contaminated saliva. Bacteria and the product of their metabolism cause inflammation of the soft tissue. Plaque buildup can become mineralized and form calculus or tartar that can pass through the gingiva, causing inflammation followed by the loss of the periodontal ligament, loss of bone, and finally the loss of the teeth. This disease process should be prevented to avoid problematic infections. Chlorhexidine has been shown to have great efficacy in preventing the formation of oral plaque and it has a strong antiseptic activity against oral pathogens. However it has the disadvantage of staining the enamel and can cause ulcerations in the mucosa and for this reason should only be used for a few days. This limits the use of chlorhexidine as a true preventive antimicrobial agent that prevents plaque formation. Veterinarians typically mix xylitol with the pet's drinking water in order to reduce the formation of oral bacterial plaque. ${ }^{17}$

Research in this area has suggested that natural products such as propolis may be of use to prevent periodontal disease. These studies indicate that propolis prevents periodontal disease by inhibition of plaque formation. It is worth noting that the antibacterial activity of these compounds is not through mechanisms that may induce bacterial resistance but instead they inhibit the attachment of the bacteria to the surface of the tooth. Studies have demonstrated that the use of ethanol extracts of propolis in the dental cavity of dogs reduces inflammation, reorganizes tissue on the surface level, and reduces bacterial activity. ${ }^{18}$ This suggests that propolis may be of use as oral antiseptic without causing side effects. ${ }^{19,20}$

\section{Ophthalmopathy}

Due to the numerous medicinal properties of propolis, it is not surprising that it has also been employed in the effective treatment of ocular diseases among humans and animals. It has been used in cats and dogs that suffer from blepharitis, infectious conjunctivitis, corneal edema, tear duct obstruction, keratoconjunctivitis sicca, corneal ulcers, and glaucoma. ${ }^{21}$ The usefulness of propolis in ophthalmic preparations was demonstrated in a study performed with 25 dogs and 5 cats that had ocular diseases. Unlike animals treated with alopatic eye- washes, those treated with propolis healed in 5-7 days for acute cases and in 10-15 days for chronic cases. Thus, propolis may be a promising therapeutic compound to treat ophthalmic diseases effectively, without side effects and at low cost. ${ }^{22}$

\section{Liver diseases}

Apiarian products have also been employed in the treatment of liver diseases. A mixture of bee pollen and propolis with a plant extract, microelements and vitamins was administered alone or in various dosing regimens ac- cording to the extent of liver disease. Clinical evaluations were performed in dogs of various ages and breeds diagnosed with hepatobilliary diseases (liver insufficiency, acute hepatitis, liver cirrhosis, and cholestasis). The methods of nutritional therapy with the mixture of bee products and plant extract were at least as effective as the standard treatment methods. ${ }^{23}$

\section{Copazan herbal gel with beepolis and wound healing in vitro: assessment of the functional biomaterial for veterinary application}

Due to our continuous interest in development of novel biomaterials for the biomedical and veterinary applications, we have formulated and evaluated Copazan Herbal Gel with Bee polis as a is a medical grade isotonic hydrogel made from high molecularweight biopolymer that has been designed to promote the wound healing in vitro and in vivo based on unique formulation of combining chitosan hydrogel and natural oils such as oleo di copaiba, calendula oil and aloevera gel provide the additional anti-inflammatory, painmanagement and wound healing properties to address all aspects of healing and wound management as well as providing additional benefits of natural oils.

The performance of the Copazan Herbal Gel ${ }^{\mathrm{R}}$ with Bee polis as a potential wound healing gel was assessed through evaluation of 
bioadhesion, inhibition zone and assessment of free radical capacity defense properties in vitro as well as demonstrate first clinical example of the improvement of wound healing in the open wound of the domestic animal after surgery.

\section{Bio-adhesion in vitro of copazan herbal gel with bee polis}

The Copazan Herbal Gel with Bee polis has been tested using Chatillon apparatus for force measurement. ${ }^{14}$ This method determines the maximum force and work needed to separate two surfaces in intimate contact. The Copazan Herbal Gel with Bee polis and combination of the starting materials $(0.1 \mathrm{~g})$ were homogeneously spread on a $1 \mathrm{~cm} 2$ glass disks and then the disks were fixed to the support of the tensile strength tester using double side adhesive. The gel was brought into contact with the commercially available pig skin, in order to simulate the skin attachment or the contact with slice of pig skin was established in order to imitate adhesion of the gel to the skin structure, after a preset contact time (1min) under contact strength $(0.5 \mathrm{~N})$ the 2 surfaces were separated at a constant rate of displacement $(1 \mathrm{~mm} / \mathrm{s})$. The strength was recorded as a function of the displacement, which allowed to determine the maximal detachment force, $\mathrm{F}_{\max }$, and the work of adhesion, W, which was calculated from the area under the strength-displacement curve.

The Copazan Herbal Gel with Bee polis showed a high adhesive force and work of adhesion in vitro. This can be expected due to the well-known intrinsic bio-adhesive properties of chitosan. The adequate water absorption capacity together with the cationic nature ${ }^{9}$ which promotes binding to the negative surface of the mucosa structure can also explain these results. Appropriate swelling is important to guarantee adhesiveness; however, over hydration can form slippery non-adhesive hydrogels. ${ }^{17,18}$ Further work is currently on the way in our laboratory to obtain further in vitro and in vivo data for the performance of Copazan Herbal Gel with Bee polis at the various $\mathrm{pH}$ conditions and concentrations in order to imitate the wound site conditions in vivo (Figure 1).

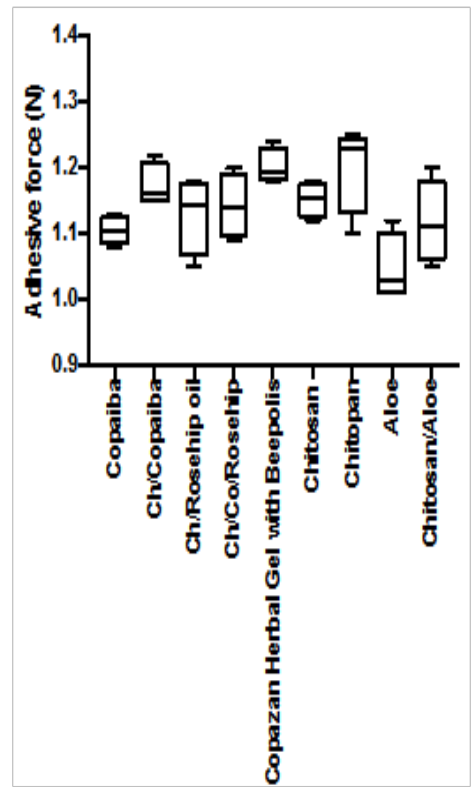

The presented values are an average $(n=5)$.

Figure I Bioadhesion of copazan herbal gel with bee polis testing in vitro.

\section{Microbiology of copazan herbal gel with bee polis and individual components}

All the test samples gave an average inhibition zone larger than the chlorhexidine gluconate control disc, thereby confirming the antibacterial activity of the Copazan Herbal Gel with Bee polis and individual combinations against Staphylococcus aureus (Figure 2).

There was a significant difference between the rest of the samples when compared to each other and the positive control. Chlorhexidine is a broad-spectrum biocide effective against Gram-positive bacteria, Gram-negative bacteria and fungi. ${ }^{19}$ Chlorhexidine inactivates microorganisms with a broader spectrum than other antimicrobials (e.g. antibiotics) and has a quicker kill rate than other antimicrobials (e.g. povidone-iodine) ${ }^{20}$ It has both bacteriostatic (inhibits bacterial growth) and bactericidal (kills bacteria) mechanisms of action, depending on its concentration. Chlorhexidine kills by disrupting the cell membrane. ${ }^{24}$ Upon application in vitro, chlorhexidine can kill nearly $100 \%$ of Gram-positive and Gram-negative bacteria within 30 seconds. ${ }^{25}$ Since chlorhexidine formulations can destroy the majority of categories of microbes, there is limited risk for the development of opportunistic infections. ${ }^{26}$

A number of mechanisms explaining the antimicrobial activity of chitosan have been postulated. ${ }^{27}$ One of the proposed mechanisms (is that the cross-linker moieties incorporated into hydrophilic chitosan increase their solubility and ease of penetration of the hydrogels into the cells of microorganisms. The chitosan then binds to microbial DNA, inhibits the transformation of mRNA and protein synthesis, and thereby inhibits metabolism. ${ }^{28}$ Another suggested antibacterial mechanism of chitosan is the interaction between positively charged protonated $\mathrm{NH}^{+}$groups of the chitosan molecules and negatively charged microbial cell surfaces. The electrostatic interaction results in changes in the properties of the cell wall permeability with leakage of the intracellular electrolytes causing internal osmotic imbalance that inhibit the growth of the microorganisms. ${ }^{29}$ The antimicrobial activity of copaiba oils was tested against Gram-positive and Gramnegative bacteria, yeast, and dermatophytes. Oils obtained from Copaifera martii, Copaifera officinalis, and Copaifera reticulata (collected in the state of Acre) were active against Gram-positive species (Staphylococcus aureus, methicillin-resistant S. aureus, Staphylococcus epidermidis, Bacillus subtilis, and Enterococcus faecalis) with minimum inhibitory concentrations ranging from $31.3-62.5 \mu \mathrm{g} / \mathrm{ml}$. The oils showed bactericidal activity, decreasing the viability of these Gram-positive bacteria within $3 h{ }^{30}$ The antibacterial and antimicrobial properties of Calendula oil are well documented and support the traditional use of the plant in the therapy of bacterial infection. ${ }^{31}$

When wound occurs, it is generally accompanied by classical symptoms of inflammation, such as pain, redness and edema. In the inflammation stage, the main aim is the removal of debris, damage tissue, and bacteria by neutrophils and macrophages, which have a role in antimicrobial defense and debridement of devitalized tissue by production of proteolytic enzyme and reactive oxygen species. ${ }^{32-34}$ The amount of uncontrolled ROS is the main cause of the inability of healing process to continue and therefore it would be ideal to utilize the antioxidant capacity of the designer hydrogels "to detect and able to "fight the free radical excess" have been assessed using previously described model using well-established that HO radical can be generated from a reaction known as the biologic Fenton reaction and this reaction requires the presence of $\mathrm{H}_{2} \mathrm{O}_{2}$. Figure 3 demonstrates 
the affects of the various antioxidant containing gels in comparison to Copazan Herbal Gel with Beepolis on the solubility of the BSA protein as an in vitro measure of the free radical defense capacity of the biomaterial in the bench mark wound healing model. Further work is on the way in our laboratory to evaluate the performance of the Copazan Herbal Gel with Beepolis in the extended in vitro model and eventually in in vivo model.
The amount of uncontrolled ROS is the main cause of the inability of the healing process to continue and therefore it would be ideal to utilize the antioxidant capacity of the "designer hydrogels" to detect and fight the free radical excess. It is well established that $\mathrm{HO}$ - can be generated from a reaction known as the Fenton reaction in the presence of $\mathrm{H}_{2} \mathrm{O}_{2}{ }^{35}$ and the generation of $\mathrm{HO} \cdot$ has been shown to be a critical factor in various ROS-induced oxidative stresses. ${ }^{36-40}$
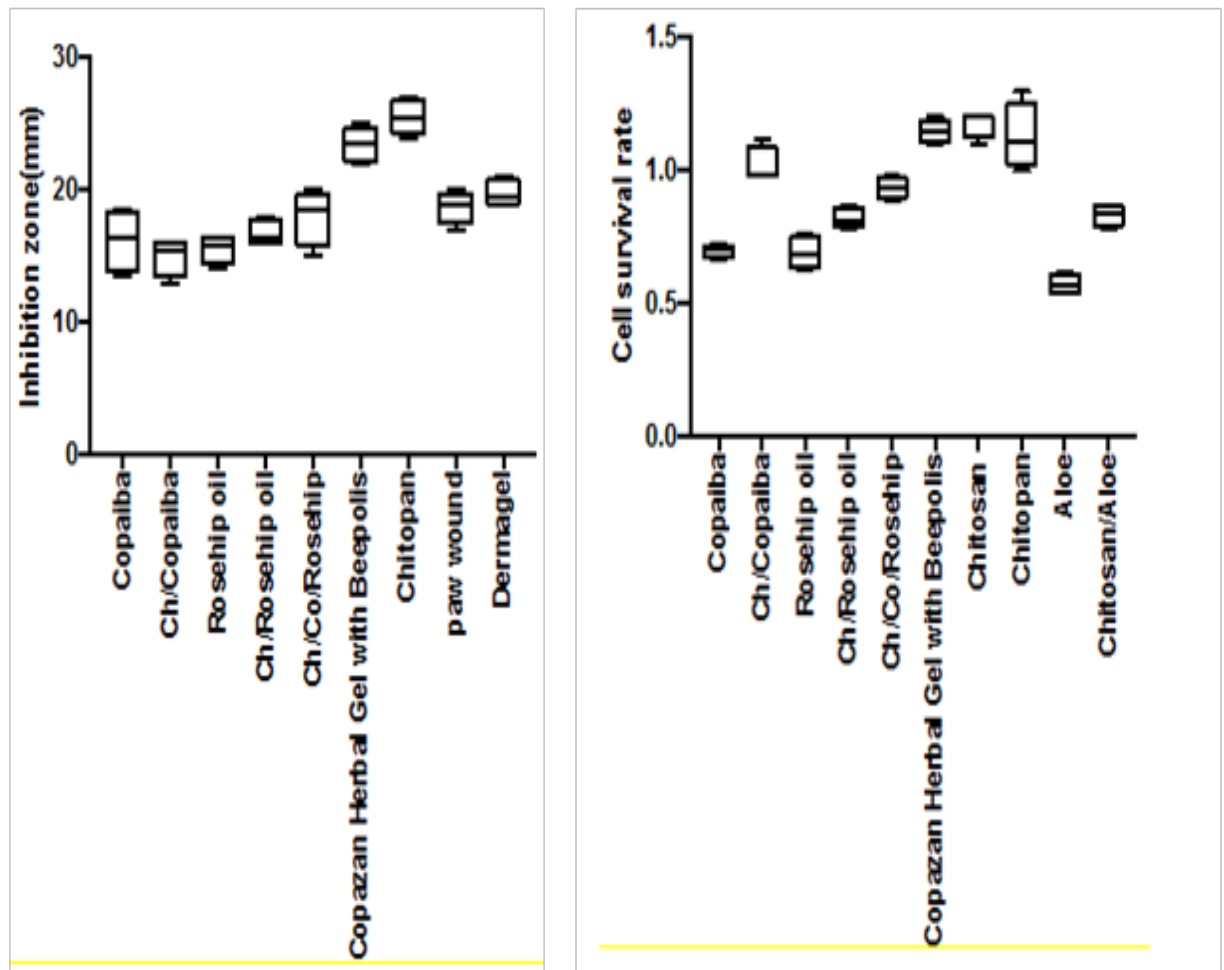

Figure $\mathbf{2}$ Inhibition zones of copazan herbal gel with bee polis and other commercial and synthetic biomaterials available for wound healing (commercially or under investigation).

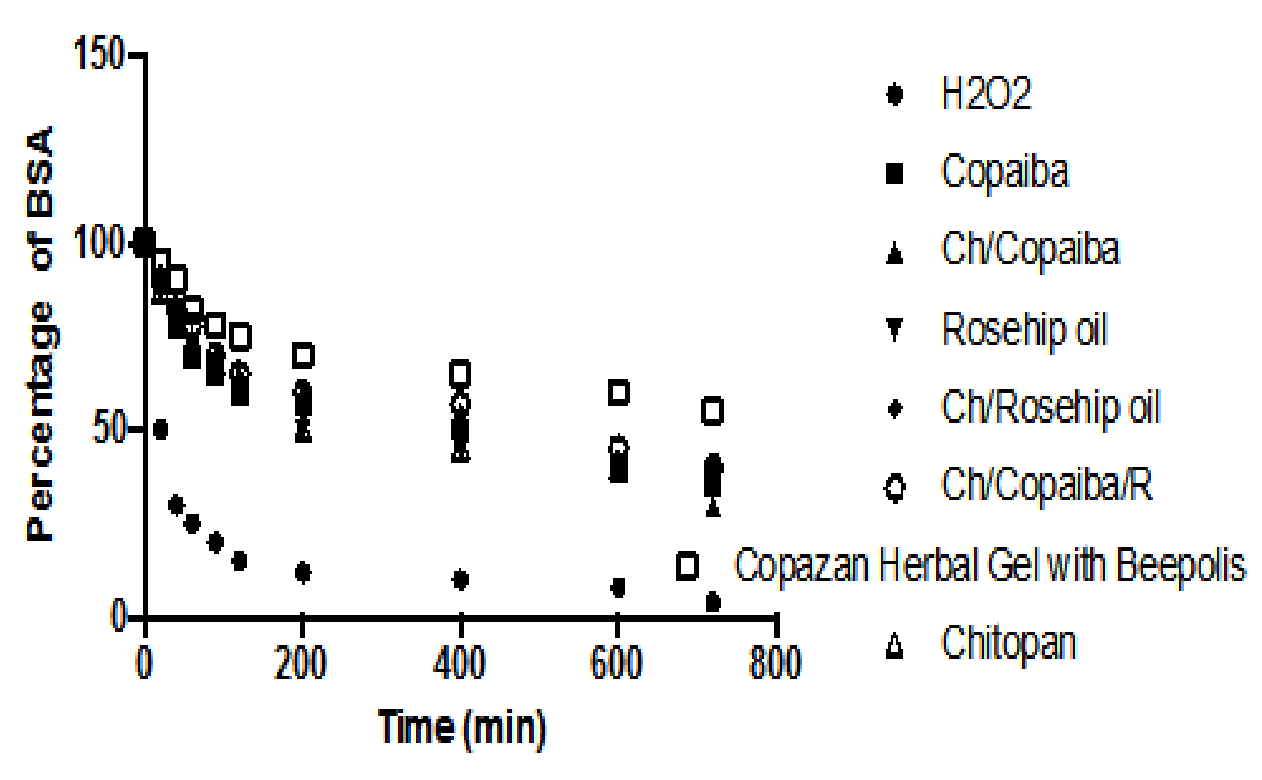

Figure 3 Affects of the various antioxidant on the solubility of BSA protein in the drug delivery system. 


\section{Clinical application of copazan herbal gel with beepolis}

(Figure 4-6).

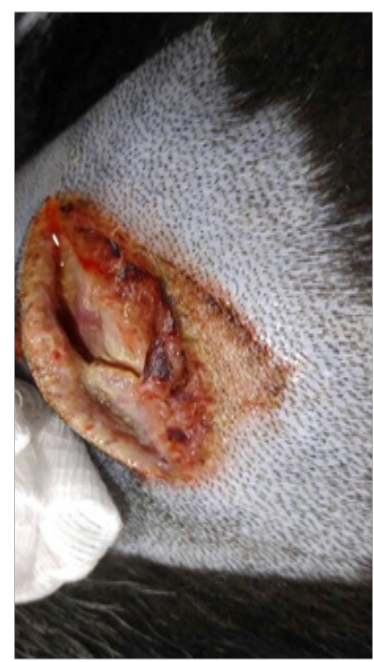

Figure 4 Before treatment with copazan herbal gel with bee polis.

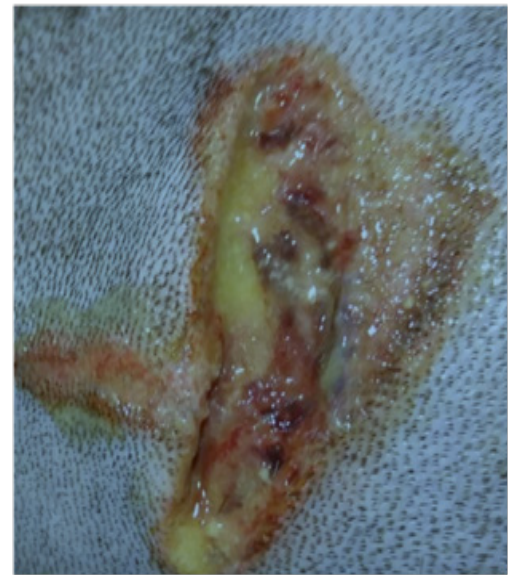

Figure 5 Treatment with copazan herbal gel with beepolis ( $3 x$ a day, open wound, protective collar used on the animal).

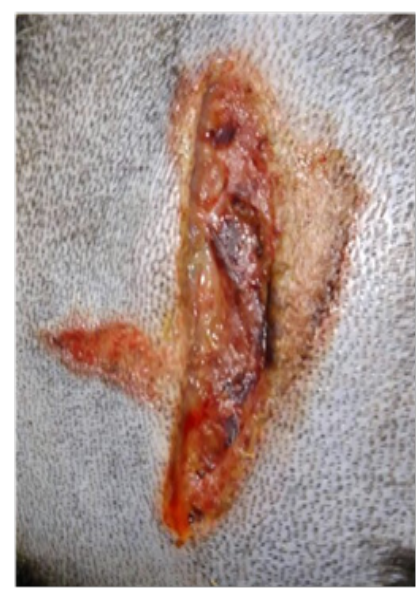

Figure 6 Treatment results after 72 hours with copazan herbal gel with bee polis.

\section{Conclusion}

The field of designer biomaterials for particular applications is growing by the day and by combining the natural medications with advances of biomaterials the advances and further applications in veterinary science can be made. Copazan Herbal Gel ${ }^{\mathrm{R}}$ with the Beepolis is a medical grade isotonic hydrogel made from high molecular weight biopolymer that promotes wound healing in vitro and limited clinical applications to date.

\section{Acknowledgements}

The acknowledgement is to Laboratory Rotterdam LTDA and VTPCHEM PTY LTD for the funding of the research.

\section{Conflict of interest}

The author declares no conflicts of interests.

\section{References}

1. Kuropatnicki AK, Szliszka E, Krol W. Historical aspects of propolis research in modern times. Evid Based Complement Alternat Med. 2013;2013:964149.

2. Bogdanov S. Propolis: composition, health, medicine: a review. Bee Product Science; 2014. p. 1-40.

3. Bassani Silva S, Sforcin JM, Amaral AS, et al. Propolis effect in Vitro on canine transmissible venereal tumor cells. Revista Portuguesa de Ciências Veterinárias. 2007;102(563-564):261-265.

4. Costa Cinegaglia N, Oliveira Bersano PR, Mendes Araújo MJA, et al. Anticancer effects of geopropolis produced by sting less bees on canine osteosarcoma cells in vitro. Evidence-Based Complementary and Alternative Medicine. 2013;ID 737386:6.

5. Perry G. The veterinary use of water preparation of propolis. Api Medica, USA: Springer; 2006.

6. Gross GS, Carvajal ILC, Principal J. Perfil de flavonoides e índices de oxidación de algunospropó- leoscolombianos. Zootecnia Tropical. 2007;25:95-102.

7. Mayta Tovalino F, Sacsaquispe Contreras S. Evaluación in Vitro del efectoantibacteriano del extractoetanólico de propóleo de Oxapampa-Perúsobrecultivos de Streptococcus mutans (ATTC 25175) y Staphylococcus aureus (ATCC 25923). Revista de Estomatologia Herediana. 2010;20:19-24.

8. Principal J, Barrios C, Tahís Pacheco N, et al. Actividadanti bacteriana in Vitro del extractoetanólico de propóleosobreunacepaclínica de Staphylococcus aureus. Gaceta de Ciencias Veterinarias. 2005;11(1):31-36.

9. Lozina L, Boehringer S, D’ Aquino M, et al. Eficacia del Propóleos sobre Malassezia pachydermatis. Correlación de distintas Técnicas in Vitro. Acta Farmacéutica Bonaerense. 2006; 25(4):560-563.

10. Lozina LA, Peichoto ME, Boehringer SI, et al. Efficacy of argentine propolis formulation for topical treatment of canine otitis extern. Arquivo Brasileiro de Medicina Veterinária e Zootecnia. 2010;62(6):1359-1366.

11. Cardoso RL, Maboni F, Machado G, et al. Antimicrobial activity of propolis extract against Staphylococcus Coagulase Positive and Malassezia pachydermatis of Canine Otitis. Vet Microbiol. 2010;142(3-4):432-434.

12. Cruz Sánchez TA, Estrada García PA, López Zamora CI, et al. Use of propolis for topical treatment of dermatophytosis in dog. Open Journal of Veterinary Medicine. 2014;4(10):239-245.

13. Abdel Fattah NS, Nada OH. Effect of propolis versus metronidazole and their combined use in treatment of acute experimental giardiasis. J Egypt Soc Parasitol. 2007;37(2 Suppl):691-710. 
14. Gressler LT, Da Silva AS, Machado G, et al. Susceptibility of Trypanosoma Evansito propolis extract in Vitro and in experimentally infected rats Res Vet Sci. 2012;93(3):1314-1317.

15. Ferreira LN, Fonseca FP, Caetano de Castro C, et al. Effect of the etanolic extract from green propolis on production of antibodies after immunization against canine parvovirus (CPV) and canine coronavirus (CCoV). Braz J Vet Res Anim Sci. 2012;49(2):116-122.

16. Ashry el SH, Ahmad TA. Review the use of propolis as vaccine's adjuvant. Vaccine. 2012;31(1):31-39.

17. Pieri FA, Falci AP, Bourguignon E, et al. Periodontal Disease in Dogs. In: Perez Marin CC editor. A Bird's-Eye View of Veterinary Medicine. In Tech, Croatia: Springer; 2012. p. 119-136.

18. Ilewicz L, Luciak M, Skrobidurska D, et al. The effect of ethanol propolis extracts on the dental pulp in dogs. Czas Stomatol. 1979;32(4):321-329.

19. Ahuja V, Ahuja A. Apitherapy-a sweet approach to dental diseases. Part II: Propolis J Academy Adv Dental Research. 2011;2(2):1-8.

20. Dantas de Almeida LF, Wanderley Cavalcanti BY, Lira Junior BR, et al. Efectoantimicótico de las tinturas a partir del propóleo y pomegranate contra las especies de Candida. Revista Cubana de Estomatología. 2012;49(2):99-106

21. Alfaris AA, Abdulsamadm RK, Swadm AA. Comparative Studies between propolis, dexametason and gentamycin treatments of induced corneal ulcer in rabbits. Iraqi Journal of Veterinary Sciences. 2009;23(Suppl 1):S75-80

22. Giral T, Hugues B, Soto CJ. Suspensión oftálmica de propóleos-R: Una alternative en el tratamiento de las oftalmopatias en animals afectivos. Revista Electrónica de Clínica Veterinaria. 2007;2(9):1-6.

23. Monteescu C, Sayuu S, Crenguta P, et al. Apiphytotherapeutic product used for nutritional therapy in dogs with liver disease. Economics, Management, and Financial Markets. 2011;6(1):1175-1178.

24. Spangberg L, Haapasalo M. Rationale and efficacy of root canal medicaments and root filling materials with emphasis on treatment outcome. Endodontic Topics. 2002;2(1):35-58.

25. Portenier I, Waltimo T, Haapsalo M. Enterococcus faecalis the roo canal survivor and 'star' in post treatment disease. Endodontic Topics. 2003;6(1):135-159.

26. Skucaite N, Peciuliene V, Vitkauskiene A, et al. Susceptibility of endodontic pathogens to antibiotics in patients with symptomatic apical periodontitis. J Endod. 2010;36(10):1611-1616.
27. Hermann B. Calcium hydroxid als Mittelzurn, Behandeln und Fullen von Wurzelkanalen. Thesis, Wurzburg, Germany: Springer; 1920.

28. Ashby M. Reactive oxygen species and dental health. Systems Biology of Free Radicals and Antioxidants: Springer; 2014. p. 3873-3897.

29. Battino M, Bullon P, Wilson M, Newman H. Oxidative injury and inflammatory periodontal diseases: the challenge of anti-oxidants to free radicals and reactive oxygen species. Crit Rev Oral Biol Med. 1999;10(4):458-476

30. Perchyonok V, Souza T, Felliti R, et al. Bio-functional nanodiamond restorative materials containing bio-additives: In Vitro approach. Open Journal of Stomatology. 2015;5(5):117-126.

31. Park JH, Saravanakumar G, Kim K, et al. Targeted delivery of low molecular drugs using chitosan and its derivatives. Adv Drug Deliv Rev. 2010;62(1):28-41.

32. Wu QX, Lin DQ, Yao SJ. Design of chitosan and its water soluble derivatives-based drug carriers with polyelectrolyte complexes. Mar Drugs. 2014;12(12):6236-6253.

33. Bauer A, Kirby W, Sherris J, et al. Antibiotic susceptibility testing by a standardized single disc method. Am J Clin Pathol. 1966;45(4):493-496.

34. Perchyonok V, Zhang S, Basson N, et al. Insights into functional tetracycline/antioxidant containing chitosan hydrogels as potential bio-active restorative materials: structure, function and antimicrobial activity. Open Journal of Stomatology. 2014;4(3):99-108

35. Kyselova Z, Rackova L, Stefek M. Pyridoindole antioxidant stobadine protected bovine serum albumin against the hydroxyl radical mediated cross-linking in vitro. Arch Gerontol Geriatr. 2003;36(3):221-229.

36. Cafaggi S, Leardi R, Parodi B, et al. Preparation and evaluation of chitosan-poloxamer 407 based matrix for buccal drug delivery. J Control Release. 2005;102(1):159-169.

37. Patel VF, Liu F, Brown MB. Advances in oral transmucosal drug delivery. J Control Release. 2011;153(2):106-116.

38. Todar K. Antimicrobial Agents in the Treatment of Infectious Disease. Online Textbook of Bacteriology. USA: Springer; 2012.

39. Mohamed N, Fahmy M. Synthesis and Antimicrobial Activity of Some Novel Cross-Linked Chitosan Hydrogels. Int $\mathrm{J}$ Mol Sci. 2012;13(9):11194-11209.

40. Barras A, Martin FA, Bande O, et al. Glycanfunctionalized diamond nanoparticles as potent E. coli anti-adhesives. Nanoscale. 2013;5(6):2307-2316. 